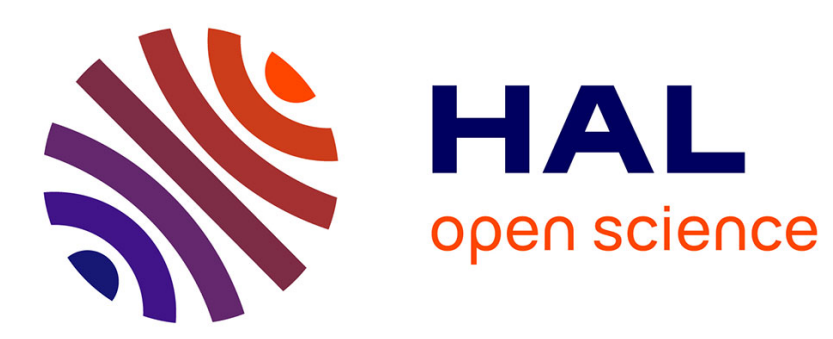

\title{
Organo-colloidal control on major- and trace element partitioning in shallow groundwaters: confronting ultrafiltration and modelling
}

Olivier Pourret, Aline Dia, Mélanie Davranche, Gérard Gruau, Odile Hénin, Maxime Angee

\section{To cite this version:}

Olivier Pourret, Aline Dia, Mélanie Davranche, Gérard Gruau, Odile Hénin, et al.. Organo-colloidal control on major- and trace element partitioning in shallow groundwaters : confronting ultrafiltration and modelling. Applied Geochemistry, 2007, 22 (8), pp.1568-1582. 10.1016/j.apgeochem.2007.03.022 . insu-00180034

\section{HAL Id: insu-00180034 https://hal-insu.archives-ouvertes.fr/insu-00180034}

Submitted on 17 Oct 2007

HAL is a multi-disciplinary open access archive for the deposit and dissemination of scientific research documents, whether they are published or not. The documents may come from teaching and research institutions in France or abroad, or from public or private research centers.
L'archive ouverte pluridisciplinaire HAL, est destinée au dépôt et à la diffusion de documents scientifiques de niveau recherche, publiés ou non, émanant des établissements d'enseignement et de recherche français ou étrangers, des laboratoires publics ou privés. 
Special issue of "Applied Geochemistry" dedicated to "Natural organic matter and its interactions with metals". Scott Smith and Fengchang Wu Editors.

\section{ORGANO-COLLOIDAL CONTROL ON MAJOR- AND}

TRACE-ELEMENT PARTITIONING IN SHALLOW

GROUNDWATERS: CONFRONTING ULTRAFILTRATION

AND MODELLING

Olivier Pourret*, Aline Dia, Mélanie Davranche, Gérard Gruau, Odile Hénin, Maxime Angée

CNRS - UMR 6118 - Géosciences Rennes

Université Rennes I - Campus Beaulieu

35042 Rennes Cedex

France

*Corresponding author: Olivier Pourret - olivier.pourret@ univ-rennes1.fr

Tel.: 33223236042 - Fax: 33223236090 


\begin{abstract}
Ultrafiltration experiments using new small ultracentifugal filter devices were performed at different pore size cut-offs to allow the study of organo-colloidal control on metal partitioning in water samples. Two shallow, circumneutral $\mathrm{pH}$ waters from the Mercy site wetland (western France) were sampled: one dissolved organic carbon (DOC)- and Ferich and a second DOC-rich and Fe-poor. Major- and trace-element cations and dissolved organic carbon concentrations were analysed and data treated using an ascendant hierarchical classification method. This reveals the presence of three groups: (i) a "truly" dissolved group ( $\mathrm{Na}, \mathrm{K}, \mathrm{Rb}, \mathrm{Ca}, \mathrm{Mg}, \mathrm{Ba}, \mathrm{Sr}, \mathrm{Si}$ and $\mathrm{Ni}$ ), (ii) an inorganic colloidal group carrying $\mathrm{Fe}, \mathrm{Al}$ and Th and (iii) an organic colloidal group enriched in $\mathrm{Cr}, \mathrm{Mn}, \mathrm{Co}, \mathrm{Cu}$ and $\mathrm{U}$. However, REE and $\mathrm{V}$ have an ambivalent behaviour, being alternatively in the organic pool and in the inorganic pool depending on sample. Moreover, organic speciation calculation using Model VI were performed on both samples for elements for which binding constants were available $(\mathrm{Ca}, \mathrm{Mg}$, $\mathrm{Ni}, \mathrm{Fe}, \mathrm{Al}, \mathrm{Th}, \mathrm{Cr}, \mathrm{Cu}, \mathrm{Dy}, \mathrm{Eu})$. Calculation shows relatively the same partitioning of these elements as ultrafiltration does. However, some limitations appear such as (i) a direct use of ultrafiltration results which tends to overestimate the fraction of elements bound to humic material in the inorganic pool as regards to model calculations as well as, (ii) a direct use of speciation calculation results which tends to overestimate the fraction of elements bound to humic material in the organic pool regards to ultrafiltration results. Beside these limitations, one can consider that both techniques, ultrafiltration and speciation calculation, give complementary information, especially for more complex samples where inorganic and organic colloids compete.
\end{abstract}

Keywords: organic matter, colloids, major and trace elements, ultrafiltration, speciation 


\section{Introduction}

Dissolved Organic Matter (DOM) is ubiquitous in aquatic and terrestrial environments and plays a key role in the geochemistry of major and trace elements (Stumm and Morgan, 1996). While DOM represents only a small proportion of the global carbon reservoir, it is instrumental in many reactions and influences environmental chemistry far beyond its mass contribution (Macalady, 1998). DOM acts as a major carrier for many elements through complexation, sorption and dissolution reactions (Buffle, 1988; Cabaniss and Schumann, 1988; Benedetti et al., 1996; Buerge-Weirich et al., 2003).

Since DOM may compete with rock surfaces because of their high sorption capacities (Iler, 1979), sorption and/or complexation of cations onto DOM are major controlling processes for element migration and removal in weathering and aquifer systems (McCarty et al., 1998; Tosiani et al., 2004; Braun et al., 2005). Moreover, speciation, bioavailability and mobility of major and trace elements can be strongly influenced by DOM (Wells and Goldberg, 1991; Tipping and Hurley, 1992; Dahlquist et al., 2004). Since in natural aquatic systems, metal ions are rarely present as free hydrated ions, DOM provides binding sites influencing both their bioavailability and general transport behaviour. It also interacts with mineral phases modifying the exchange rates with solutions and constrains part of elemental mobility (Bennett and Siegel, 1987; Christensen et al., 1996; Schmitt et al., 2003).

Colloids, ubiquitous in natural waters, either organic or inorganic, are microscopic particles with size in the range $1 \mu \mathrm{m}$ to $1 \mathrm{~nm}$ (Stumm and Morgan, 1996). Because of their small size, they tend not to settle out of suspensions, being influenced by Brownian motion and minor currents in the bulk solutions. The solid-water interface established by these microparticles plays a key role in regulating the concentrations of most reactive elements and of many pollutants in soils and natural waters (Stumm and Morgan, 1996). They adsorb heavy 
metal ions and waterborne pollutants governing, via their movements in aqueous systems, the fates of reactive elements and/or pollutants.

Recent studies coupled or not with speciation calculations suggested that a large fraction of trace elements are closely associated with DOM including colloidal organic matter in many natural waters (Tanizaki et al., 1992; Viers et al., 1997; Dupré et al., 1999; Dia et al., 2000; Ingri et al., 2000; Gruau et al., 2004; Johannesson et al., 2004). Moreover, redox conditions do control the dynamics and fate of some toxic and/or redox sensitive elements at the soil/water interface. The true respective roles of DOM and Fe-Mn oxyhydroxides as elemental carriers are still poorly understood. As Fe-Mn oxyhydroxides are redox sensitive (Stumm and Morgan, 1996), it is not clear whether trace metals are directly bound to the oxyhydroxides and complexed by DOM when the oxyhydroxides are dissolved during reduction, or whether they are directly bound to DOM and controlled by the organic matter dynamics throughout the entire redox cycle.

Considering that the respective contribution of organic and inorganic element carriers still remains a matter of debate, this work is dedicated to (i) investigate trends in trace element partitioning in size fractionated samples of well water using small ultracentrifugal devices and (ii) compare this field data to geochemical modelling calculations.

\section{Samples}

\subsection{Sample location}

The Kervidy/Coët-Dan catchment $\left(5 \mathrm{~km}^{2}\right)$ is located in the Coët-Dan drainage basin, about $100 \mathrm{~km}$ southwest of Rennes in Central Brittany, France (Fig. 1). The bedrock is made of fissured and fractured upper Proterozoic schists (Dabard et al., 1996). The soils, developed 
into a loamy material derived from bedrock weathering and eolian Quaternary deposits, exhibit facies variations, which are locally, dominated by silt, clay or sandstone materials (Pellerin and Van Vliet-Lanoë, 1994). The mineralogical composition of schist was determined from drill cutting analysis and includes (in decreasing relative proportion): quartz, muscovite, chlorite, K-feldspar and plagioclase (Pauwels et al., 1998). The soil horizons comprise a large number of secondary mineral phases including illite, smectite, kaolinite, various Fe-oxides and Fe-oxyhydroxides (hematite, goethite...) and Mn oxides (Pauwels et al., 1998; Curmi et al., 1995).

Previous hydrochemical studies (Durand and Torres, 1996; Jaffrézic, 1997; Dia et al., 2000; Molénat et al., 2002) showed that the Kervidy/Coët-Dan groundwater can be summarized by the contrast of two spatially-distributed chemical domains. These include: (i) the uppermost part of the groundwater, sampled below the hillslope, and which is colourless, slightly acidic, always oxidized and nitrate-contaminated (up to $200 \mathrm{mg} \mathrm{L}^{-1} \mathrm{NO}_{3}{ }^{-}$) (Molénat et al., 2002), (ii) the shallow groundwater domain located in the wetlands where the water table reaches the organic-rich upper soil horizons. This second groundwater component is coloured, DOC-rich and exhibits variable nitrate concentrations (Durand and Torres, 1996; Jaffrézic 1997). In addition, these waters are characterized by the development of periodic reducing conditions mostly in late winter and spring, which is a direct consequence of the waterlogging of the uppermost soil horizon (Jaffrézic, 1997).

\subsection{Sampling procedure}

Two organic-rich groundwater samples were collected from shallow wells (PF1, 0.5m- and PF3, 0.8-m-deep) located in the Mercy wetland (Fig. 1) in November 2004. Physicochemical parameters ( $\mathrm{pH}$ and temperature) were measured directly in the field. The $\mathrm{pH}$ was 
measured with a combined Sentix 50 electrode after a calibration performed with WTW standard solutions $\left(\mathrm{pH}=4.01\right.$ and 7.00 at $\left.25^{\circ} \mathrm{C}\right)$. The accuracy of the $\mathrm{pH}$ measurement is \pm $0.05 \mathrm{pH}$ unit. Samples used for determination of dissolved $(<0.2 \mu \mathrm{m})$ major-, trace-element and DOC concentrations were pumped using Teflon tubing connected to a polyethylene syringe. The collected waters (about $1 \mathrm{~L}$ ) were immediately filtered on site using $0.2 \mu \mathrm{m}$ cellulose acetate filter capsule (polyether sulfone membrane Sartorius Minisart), and stored in pre-cleaned, acid-washed polyethylene bottles. About $30 \mathrm{~mL}$ were used to measure alkalinity, major anions and DOC concentrations. The remaining solution was used to measure major and trace cation concentrations and was then successively filtered through ultracentrifugal devices with decreasing pore size cut-offs in order to allow separation of colloids from "truly" dissolved forms.

\section{Experimental}

\subsection{Ultrafiltration set-up description and chemical analysis}

To separate the colloidal bound elements from the non colloid-borne elements ultrafiltration experiments were performed on these samples using $15 \mathrm{~mL}$ centrifugal tubes (Millipore Amicon Ultra-15) equipped with permeable membranes of decreasing pore sizes

(30 kDa, $10 \mathrm{kDa}$, and $5 \mathrm{kDa}$ with $1 \mathrm{Da}=1 \mathrm{~g} \mathrm{~mol}^{-1}$ ). Metal-colloid complexes are retained by the ultrfiltration membrane while free ions and smaller complexes pass into ultrafiltrate. The degree of metal-colloid complexation is usually determined from the metal concentration in the ultrafiltrate relative to the original solution. Each centrifugal filter device was washed and rinsed with $\mathrm{HCl} 0.1 \mathrm{~N}$ and MilliQ water two times before use. The starting filtrate had been passed through $0.2 \mu \mathrm{m}$ filter, and then aliquots of these filtrates were passed through 
membranes of smaller sizes. All ultrafiltrations of the $0.2 \mu \mathrm{m}$ filtrates were done in parallel. The centrifugations were performed using a Jouan G4.12 centrifuge equipped with swinging bucket at about $3000 \mathrm{~g}$ for 20 minutes and 30 minutes, for $30 \mathrm{kDa}$ and $10 \mathrm{kDa}$, and $5 \mathrm{kDa}$ devices, respectively (centrifugation times determined from preliminary experiments not shown). All experiments were carried out at room temperature: $20 \pm 2{ }^{\circ} \mathrm{C}$.

Major cations and trace elements concentrations were determined at Rennes 1 University using an Agilent Technologies ${ }^{\mathrm{TM}}$ HP4500 ICP-MS instrument. Quantitative analyses were performed using a conventional external calibration procedure. Three external standard solutions with major and trace elements concentrations similar to the analyzed samples were prepared from mono- and multi-elements standard solutions (Accu Trace ${ }^{\mathrm{TM}}$ Reference, USA). Indium was added to all samples as an internal standard at a concentration of $0.87 \mu \mathrm{mol} \mathrm{L}^{-1}(100 \mathrm{ppb})$ to correct for instrumental drift and possible matrix effects. Indium was also added to the external standard solutions. Calibration curves were calculated from measured major cations and trace elements /indium intensity ratios. The instrumental error on major cations and trace elements analysis in our laboratory as established from repeated analyses of the SLRS-4 water standard is $< \pm 2 \%$. DOC concentrations were determined at Rennes 1 University using a Shimadzu 5000 TOC analyzer. The accuracy of DOC concentration measurements is estimated at $\pm 5 \%$ as determined by repeated analyses of freshly prepared standard solutions (potassium biphtalate). Total alkalinity was determined by potentiometric titration with an automatic titrating device (794 Basic Titrino Methrom). Major anions $\left(\mathrm{Cl}^{-}, \mathrm{SO}_{4}{ }^{2-}\right.$ and $\left.\mathrm{NO}_{3}{ }^{-}\right)$concentrations were measured by ionic chromatography (Dionex DX-120): the uncertainty is below $\pm 4 \%$.

The same material was used for all filtrations, molecular size exclusion rather than adsorption onto membranes should control the colloid distributions between ultrafiltrates. The selectivity of the 10 and $5 \mathrm{kDa}$ membranes regards to Aldrich Humic Acid, with a mean 
molecular weight of $23 \mathrm{kDa}$, was verified by monitoring the Dissolved Organic Carbon (DOC) contents of the ultrafiltrates (preliminary experiments not shown). Results show that the latter were systematically lower or equal to blank values ( $\leq 1 \mathrm{ppm})$. Possible adsorption of inorganic major and trace elements species onto the membrane or onto cell walls was also monitored. Inorganic multi-elements solutions of known concentration were ultrafiltrated several times. Results showed that $100 \%$ of the major and trace elements present in solution was recovered in the ultrafiltrates, demonstrating that no major and trace elements was adsorbed neither on the membranes nor on the walls of the cell devices used. All ultrafiltration were performed in duplicate. A good reproducibility is observed for DOC and major and trace elements concentrations. Duplicates are better than $5 \%$ for most elements except for some trace elements in the lower pore size cut-off fraction (i.e. in the $<5 \mathrm{kDa}$ fraction, about $10 \%)$.

All procedures (sampling, filtration, storing and analysis) were carried out in order to minimize contamination. Samples were stored in acid-washed Nalgene polypropylene containers before analyses. Chemical blank concentrations of individual major cations and trace elements were all better than than $2 \%$ for all studied elements except for DOC, $\mathrm{Al}$ and $\mathrm{Cu}(<8 \%, 10 \%$ and $11 \%$, respectively $)$.

\subsection{Speciation calculation}

The aqueous speciation of some major $(\mathrm{Al}, \mathrm{Ca}, \mathrm{Fe}, \mathrm{Mg})$ and trace elements $(\mathrm{Cu}, \mathrm{Eu}$, Dy, Th) was calculated using the computer program WHAM 6 (Version 6.0.13). It includes Model VI which has been described in detail by Tipping (1998). The model is a discrete binding site model in which binding is modified by electrostatic interactions. There is an empirical relation between net humic charge and an electrostatic interaction factor. In this 
study the computation is performed using only the default parameters values and the generic $\log \mathrm{K}_{\mathrm{MA}}$ values (see Tipping, 1998). Humic substances were the only colloidal phases considered in this calculation, none colloidal oxide phase was considered.

\subsection{Data treatment}

The ascending hierarchical classification using Ward criterion was performed through SPAD 4.5 routines (DECISIA, France) so as to implement sample classification (Dillon and Goldstein, 1984). This method is based on squared Euclidian distances between individuals in the space formed by the available variables. The initial sample is partitioned into several classes of individuals so as to maximise interclass inertia (i.e. to maximise variability between groups) and minimise intraclass inertia (i.e. to maximise homogeneity in each group). As for factor analysis, the raw data matrix was introduced in principal component analysis, without any rotation. The input data are the whole set of ultrafiltrates after each cut-off for all considered elements.

\section{Results}

\subsection{Ultrafiltrations}

In the following sections the behaviour of major, trace, and DOC concentrations obtained for successive ultrafiltrations will be discuss. Major, trace element, and DOC concentrations are reported in Table 1. Major anions are not considered in this part of the study. Ultrafiltration data are presented following the hierarchical classification described in the hereabove "data treatment" paragraph. The results of cluster analysis are presented as a 
dendogram, where the similarity of two elements is conversely proportional to the linkage distance (Fig. 2). This graph reveals three clusters: (i) cluster I includes alkalis ( $\mathrm{Na}, \mathrm{K}, \mathrm{Rb}$ ), alkaline earth metals ( $\mathrm{Ca}, \mathrm{Mg}, \mathrm{Ba}, \mathrm{Sr}$ ) as well as $\mathrm{Si}$ and $\mathrm{Ni}$, (ii) cluster II contains $\mathrm{Cr}, \mathrm{Mn}, \mathrm{Co}$, $\mathrm{Cu}$ and $\mathrm{U}$ and (iii) cluster III includes $\mathrm{Al}, \mathrm{Fe}$ and Th. REE and V are either, in cluster II or, in cluster III for PF1 and PF3 samples, respectively.

As stated previously, colloids span a wide range from about $1 \mathrm{~nm}$ to a few $\mu \mathrm{m}$; successive ultrafiltrations through decreasing pore size membranes, DOC concentrations decrease in the ultrafiltrates (Fig. 3). These successive ultrafiltrations allow further consideration about various molecular weight humic substances. To determine whether metals are bound or not to humic substances, metal concentrations will be systematically plot as a function of DOC concentrations.

\subsubsection{Common elemental distribution in the two samples}

(i) cluster I : "truly" dissolved behaviour

Concentrations of $\mathrm{Rb}$ and other alkalis such as $\mathrm{Na}$ and $\mathrm{K}$, are not affected by ultrafiltrations since no fractionation occurs when following the decreasing pore sizes or the DOC concentrations (Fig. 4a). Alkaline elements behave as "truly" dissolved in the form of inorganic species as often reported in the literature (Pokrovsky and Schott, 2002 and references therein).

Major and trace alkaline earth $(\mathrm{Ca}, \mathrm{Mg}, \mathrm{Sr}$ and $\mathrm{Ba})$ concentrations do not change significantly during filtration except for the smallest pore size $(5 \mathrm{kDa})$. The small drop between $5 \mathrm{kDa}$ and $10 \mathrm{kDa}$ filtrates (Fig. 4b) can suggest that part of these elements (about 10 $\%$ ) could be associated with low-molecular weight organic colloids as reported elsewhere 
where complexes of $\mathrm{Ca}$ and $\mathrm{Mg}$ with natural fulvic acids have been identified (Shapiro, 1964).

Si concentrations display no significant variations in the successive filtrates. This suggests that aqueous silica is not trapped by organic colloids (Pokrovski and Schott, 1998) and/or by small-size clay minerals or phytolites. Ni concentrations do not exhibit large variations through the different decreasing pore size cut-offs suggesting that this transition metal has to be mostly present as "truly" dissolved species or small size inorganic complexes.

(ii) cluster II: organic colloidal pool-borne elements

Both $\mathrm{Cu}$ and $\mathrm{U}$ concentrations display extremely regular linear relationship as reported versus DOC concentrations for both samples (Figs. 5a, 5b ; Table 1). The linear relationships suggests that these two trace elements are strongly bound to organic matter and probably complexed to very low molecular weight organic ligands such as extracellular ligands as well as, larger size colloids such as fulvic and/or humic acids, cell fragments or bacteria as elsewhere reported (Xue et al., 1995; Sigg et al., 2000). Since Cu and U concentrations tend to zero before DOC ones do, one can suggests that no fraction of $\mathrm{Cu}$ and $\mathrm{U}$ occurs as free species in solutions and that a fraction of DOM is unable to complex these two elements. However, organic matter remains the major carrier of $\mathrm{Cu}$ and $\mathrm{U}$ as often previously stated (Stumm and Morgan, 1996).

$\mathrm{Cr}, \mathrm{Mn}$ and Co concentrations (Table 1) also display linear positive correlations when reported versus DOC concentrations for both samples. Organic matter is thus also a major carrier of these elements.

(iii) cluster III: inorganic colloidal pool-borne elements 
$\mathrm{Al}$ and $\mathrm{Fe}$ concentration variations through successive filtrations (Fig. 6a and 6b) suggest that these elements do not occur as free species in solution, and that two types of colloids can carry these metals (i.e. Al-, Fe- rich inorganic colloids or organic-, Al-, Fecomplexing colloids). $\mathrm{Al}$ and Fe concentrations vary following the same trend (Table 1) both strongly affected by a large drop of concentrations between $0.2 \mu \mathrm{m}$ and $30 \mathrm{kDa}$ filtrations. Up to $96 \%$ and $75 \%$ for $\mathrm{Fe}$ and $\mathrm{Al}$, respectively, are removed by the first ultrafiltration step. This indicates a major control of $\mathrm{Al}$ by inorganic mixed Fe/Al oxyhydroxides as already reported (Pokrovsky and Schott, 2002; Geckeis et al., 2003). This is particularly true for Alrich PF3 sample as compared to PF1 where Fe dominates regards to Al. However, a small part of $\mathrm{Al}$ and $\mathrm{Fe}$ could be partially bound to low-molecular weight organic-rich colloids. Al concentration tends to zero before DOC does for both samples. This is not the case for Fe, since Fe disappears before DOC does. This suggests that the Fe budget between organic and inorganic carrier phases has to be different from that of $\mathrm{Al}$, depending also which sample is considered. Furthermore, Al could be carried by another low-molecular weight DOC-poor phase which does not trap Fe in PF1 sample, but not in PF3. Al cannot be present as clay colloids since Si occurs at "truly" dissolved state.

Thorium concentrations regularly decrease through the successive decreasing pore size cut-offs with a large drop (up to $40 \%$ ) between $0.2 \mu \mathrm{m}$ and $30 \mathrm{kDa}$ (Fig. 6c). This suggests that this fraction of Th has to be associated to large size organic colloids while about $60 \%$ of Th appears to be carried by colloids smaller than $30 \mathrm{kDa}$. Th concentrations decrease quicker than do DOC concentrations suggesting that Th is probably mostly carried in solution by high-molecular weight organic-rich colloids. Th concentration versus Al concentration diagram (Fig. 6d) suggests that Th might be also partly carried by Al-rich phases as well as 
DOC-rich ones. Clays and clay-organic complexes could be possible Th carriers in these waters.

\subsubsection{Peculiar elemental distribution in the DOC-depleted sample}

REE and V display an ambivalent behaviour regards to sample considered. Plot of $\Sigma$ REE concentrations versus DOC concentrations for the successive ultrafiltrations (Fig. 7a) show a general decreasing tendency going through zero REE that illustrates the removing of REE jointly to DOC. However, there is still DOC left in solution as REE concentrations are close to zero, which allows us to extrapolate that not all the organic pool is able to complex REE. The REE appear to be strongly complexed by high-molecular weight organic matter as previously stated in other ultrafiltration studies (Sholkovitz, 1995; Viers et al., 1997; Dia et al., 2000). However, a recurrent problem of ultrafiltration studies is that $\mathrm{Fe}$ and $\mathrm{Mn}$ oxyhydroxides can be present in the waters along with organic colloids, some of them being potentially strong competitors of organic matter for REE complexation (Bau, 1999; Dupré et al., 1999). PF1 sample presents a significant decrease in its Fe content upon ultrafiltration at the $30 \mathrm{kDa}$ ultrafiltration step. This decrease corresponds to a marked change in the slope of the REE-DOC linear relationships otherwise observed in the REE versus DOC variation diagrams (Fig. 7a). About $80 \%$ of the REE and $96 \%$ of the Fe, but only $9 \%$ of the DOC, are removed during the first ultrafiltration step of this sample. Such a relationship strongly suggests that the "colloidal" REE budget of PF1 samples is controlled, in part, by REEbearing Fe colloids as suspected by looking at Fig. 7b. By contrast for PF3 sample, REE concentrations display a strong correlation as reported versus DOC concentrations irrespective of the cut-off. The linear relationship suggests that in this sample REE are strongly bound to organic matter. 
Vanadium concentrations reported versus DOC concentrations display a large drop between $0.2 \mu \mathrm{m}$ and $30 \mathrm{kDa}$ filtrations in the two samples (Fig. 7c). This suggests that a significant fraction (about $40 \%$ ) of $\mathrm{V}$ has to be carried by large size organic colloids. By contrast, when looking at lower cut-off the $\mathrm{V}$ concentrations behave differently in the two samples. On one side for the uppermost sample (PF1) a three step-shape decrease following DOC concentrations lowering suggesting that $\mathrm{V}$ remains carried by the organic phase (lowand high-molecular weight). Whereas on the other side, the decrease of $\mathrm{V}$ concentrations follows that of $\mathrm{Al}$. This suggests that as do Th concentrations regards to $\mathrm{DOC}$ and $\mathrm{Al}$ concentrations, V concentrations follow the same trend (Fig. 7d). Both V and Th concentrations in organic-rich upper level seem to be controlled by mixed DOC/Al-rich phases, whatever may be the pore size cut-off. Moreover, the large decrease of $\mathrm{V}$ concentrations following that of Fe between $0.2 \mu \mathrm{m}$ and $30 \mathrm{kDa}$ suggests that Fe-rich phases exert as well an important control on the speciation of $\mathrm{V}$ at this cut-off as earlier reported (Pokrovsky and Schott, 2002). At lower filtration sizes, V concentrations tends to zero, suggesting that $\mathrm{V}$ has also to be carried by a mixed Al/Fe/DOC-rich phase. The lower sample (PF3) displays a strong decrease in the first filtration step which implies that $\mathrm{V}$ is strongly bound to high-molecular weight organic material, and a constant V concentration after the 30 $\mathrm{kDa}$ filtration which implies that $\mathrm{V}$ behaves independently of DOC. However, the $\mathrm{V}$ concentration pattern is different in the DOC-depleted sample with no variation versus $\mathrm{Al}$ concentrations after the $30 \mathrm{kDa}$ filtration. This suggests that $\mathrm{V}$ is not carried by an Al-rich phase, but mostly occurs as "truly" dissolved species as free hydrated ion.

\subsection{Speciation calculations}


The aqueous speciation of some major $(\mathrm{Ca}, \mathrm{Mg}, \mathrm{Al}, \mathrm{Fe})$ and trace elements $(\mathrm{Cr}, \mathrm{Ni}$, $\mathrm{Cu}, \mathrm{Eu}, \mathrm{Dy}, \mathrm{Th}$ ) in the two samples are calculated using Model VI (Tipping, 1998). The $\mathrm{pH}$ values were fixed at 7.08 and 6.93 , for PF1 and PF3 samples, respectively. The DOC concentrations as well as major and trace elements concentrations input in the model were those displayed in Table 1. The Humic Acid (HA) and Fulvic Acid (FA) contents necessary to run both models are assumed to be equal to the difference between the DOC content of the < $0.2 \mu \mathrm{m}$ fraction and that of the $<5 \mathrm{kDa}$ fraction for $\mathrm{HA}$, and to the $\mathrm{DOC}$ content of the $<5$ $\mathrm{kDa}$ fraction for FA. Fractions of elements complexed to humic substances samples are reported in Table 2. As for the ultrafiltrations experiments three distinct groups appear from the calculations: (i) $\mathrm{Mg}, \mathrm{Ca}, \mathrm{Ni}$ appear to be mainly present as "truly" dissolved species in the solution, $<8 \%$ of elements are complexed to humic substances. (ii) $\mathrm{Fe}$ and $\mathrm{Al}$ are partly complexed to organic matter; between 16 and $81 \%$ of these elements are bound to humic substances. Al is more strongly bound to humic substances than Fe does. (iii) According to calculations $\mathrm{Cr}, \mathrm{Cu}, \mathrm{Eu}, \mathrm{Dy}$ and $\mathrm{Th}$ exhibit comparable speciation : $>86 \%$ (except $\mathrm{Cu}$ for PF1 sample) of elements are complexed by humic substances.

\section{Confronting speciation calculations with ultrafiltration data}

The need for the knowledge of "truly" dissolved and colloidal concentrations includes several points such as (i) an understanding of element geochemical cycles and partitioning, (ii) a better prediction of element fate in polluted environments, or (iii) the relevance to bioavailability issues. The comparison between results obtained by ultrafiltration and by speciation calculation leads to some comments. Three groups can be considered.

For $\mathrm{Mg}$ and $\mathrm{Ca}$ the results of speciation calculation are in good agreement with the ultrafiltration data. These elements behave as "free" ions in the dissolved pool in the form of 
inorganic species. Speciation calculations performed for $\mathrm{Cr}, \mathrm{Cu}, \mathrm{Dy}, \mathrm{Eu}$ and Th give a higher proportion of elements bound to humic substances than those recovered from ultrafiltration data. By contrast, for $\mathrm{Al}, \mathrm{Fe}$ and $\mathrm{Ni}$ speciation calculations give a slightly lower proportion of elements bound to humic substances as compared to those obtained from ultrafiltration data. Even if there are slight differences between ultrafiltration and speciation calculations, trends are relatively similar for $\mathrm{Al}, \mathrm{Dy}, \mathrm{Eu}$ and Th. Major differences evidenced for $\mathrm{Cr}, \mathrm{Cu}, \mathrm{Fe}$ and $\mathrm{Ni}$ could be explain by the fact models need improvement as already stated for $\mathrm{Cu}$ and $\mathrm{Ni}$ (Unsworth, 2006).

Since the binding constants with humic substances are not available for the whole set of studied elements, the speciation calculations were performed for part of them. However, the calculations were achieved for one or several elements belonging to each of the three groups, allowing these elements to be considered as a "pilot study" for each group. In the following, the discussion will be focused on these "pilot study" elements considering that these latter are representative of the elements within the different groups.

\section{1. "Truly" dissolved elements}

Concentrations of alkalis and alkaline earth elements (major and trace ones) appear to be not significantly affected by ultrafiltrations suggesting that they are part of the dissolved pool. Since there is no clear relationship between DOC or Fe and these elemental concentrations, one can consider that these species do not occur as small-size organic or inorganic complexes in the dissolved pool. The speciation calculations performed during this study for alkalis and alkaline earth metals agree with ultrafiltration data. The occurrence of these metals in the dissolved pool was predictable since these elements belong to the class A ion group following the Nieboer and Richardson (1980) classification of elements. The so- 
called A group corresponds to metals with spherical symmetry and low polarizability. Aside from the metallic form, they always have a single oxidation state $(+1)$ or $(+2)$ for alkalis and alkaline earth elements, respectively (Ahrland et al., 1958; Nieboer and Richardson, 1980). This implies that they are not directly influenced by the redox status of the water and that they display the lowest stability complexes. Si, which also belongs to the type A group following Nieboer and Richardson classification, displays no significant variation of concentrations throughout the ultrafiltration procedure. This suggests that Si has also to be considered as a "truly" dissolved element. Although not part of the A class group, but part of the so-called "borderline" group (Nieboer and Richardson, 1980), Ni and Co behave also as "truly" dissolved ions as do alkalis and alkaline earth metals.

\subsection{Complexed metals}

It is now widely accepted that colloidal material plays a significant role in the transport and cycling of trace metals in waters. However, as often debated elsewhere (Lyven et al., 2003 and references therein) the key question is which is the true competition between Fe- and C-based colloidal carriers for trace metals?

\subsubsection{The inorganic colloidal pool as a metal carrier}

Fe, unlike DOC is strongly affected by the first ultrafiltration step (i.e. $30 \mathrm{kDa}$ ). Fe is present as large-size colloids and is almost completely removed from solution after this first step. Fe and DOC behave independently during the ultrafiltration. Al, like Fe, is strongly affected by the first ultrafiltration step. Fe oxyhydroxides are though much more soluble than Al ones do (Stumm and Morgan, 1996). PF1 sample displays a strong dominance of Fe over 
Al, with a Fe/Al molar ratio as high as 20 . In PF3 sample the Fe/Al molar ratio is smaller with Fe and $\mathrm{Al}$ concentration being present in equal proportion. Moreover, $\mathrm{Al}$ concentration is well correlated with that of Fe and is only weakly dependent on DOC. This indicates a control of Al by inorganic mixed Fe/Al oxyhydroxides colloids. However, the major controlling parameter remains $\mathrm{pH}$ which governs solubility of $\mathrm{Fe}$ oxyhydroxides and therefore the release and trapping of associated trace metals.

Thorium follows closely aluminum, being mostly controlled by Fe/Al oxyhydroxides. Its concentration strongly decreases with the decrease of $\mathrm{Al}$ and $\mathrm{Fe}$ concentrations in the filtrate whereas it does not depend on DOC concentrations. Th is generally known to be immobile during weathering, accumulating in residual phases. However, his migration is possible in organic- and Fe/Al-rich waters (Pokrovsky and Schott, 2002). Mixed Fe/Al colloids are essentially responsible for these concentrations as already observed elsewhere (Pokrovsky and Schott, 2002; Geckeis et al., 2003). However, this result is different from those already published by Viers et al. (1997) where this element appears to be exclusively controlled by DOC. Even if adsorption of organic matter would result in a negative surface charge on the iron colloid surface, the negative surface charge density would be significantly less than that at purely humic colloids so that a significant difference in electrostatic binding would still be expected. Thus, Fe/Al oxyhydroxides remain the major complexing agent of $\mathrm{Th}$ and in this case Th is mostly controlled by Fe/Al oxyhydroxides colloids.

Model VI tends to underestimate the proportion of metal bound to humic substances as compared to ultrafiltration data (Fig. 8). It is important to note that the $<5 \mathrm{kDa}$ fraction is considered as free species, which is not true as fulvic acids are characterized by lower molecular weight. Thus, if the fraction $>5 \mathrm{kDa}$ is considered to be the humic bound fraction and as the correlation between $\mathrm{DOC}$ and $\mathrm{Fe}$ and $\mathrm{Al}$ shows no common behaviour, ultrafiltration experiments should be taken into account carefully. Such a direct use of 
ultrafiltration results led to an overestimation of elements bound to humic substances regards to Model VI calculations.

\subsubsection{The organic colloidal pool as a metal carrier}

$\mathrm{REE}$ and $(+2)$ cations $(\mathrm{V}, \mathrm{Cr}, \mathrm{Mn}, \mathrm{Co}, \mathrm{Cu})$ of the first transition series show strong correlation with DOC. These cations are all A-Type (Nieboer and Richardson, 1980), where electrostatic binding dominates over covalent one. It is therefore more expected for the smaller cations in each series to be associated with strongly negatively charged organic (humic) colloids than with iron colloids with small positive charge for circumneutral $\mathrm{pH}$ samples (Stumm and Morgan, 1996). Among the transition metals, the sequence of complex stability is known to be $\mathrm{Mn}^{2+}<\mathrm{Co}^{2+}<\mathrm{Ni}^{2+}<\mathrm{Cu}^{2+}$, a sequence known as the Irving-Williams Series. As expected $\mathrm{Cu}$ appears to be the most strongly bound to organic ligands as evidenced elsewhere (Buerge-Weirich et al., 2003). Xue and Sigg (1993) and Tipping et al. (2002) suggested that such strong binding has to be related to highly selective organic ligands, released by phytoplankton in order to control metal levels in their immediate environment. Pronounced differences are observed in this study as compared to what is expected for the other transition metals (Eyrolle et al., 1993) with for example Ni occurring in the "truly" dissolved pool. This may be caused by the fact that organic molecules can often be characterized by more than one functional group and hence can coordinate a metal at several positions (Stumm and Morgan, 1996). Moreover, data are consistent with dominance of organic matter complexation of REE (Johannesson et al., 2004), even if REE in the highmolecular weight fraction (i.e. $>30 \mathrm{kDa}$ ) of PF1 sample seem to be complexed with $\mathrm{Fe}$ oxyhydroxides. These results are also consistent with evaluation made on models calculations onto REE speciation (Pourret et al., 2006). 
In contrast, uranium may form oxocation $\mathrm{UO}^{2+}$ at equilibrium in oxic waters. This cation is known to have a very strong affinity for carbonate ions. While carbonate concentrations are very low in the circumneutral $\mathrm{pH}$ groundwaters, binding to carboxylate and/or phenolate groups, which represent major functional group in humic substances (Aiken et al., 1985), may contribute to the observed association of U with organic colloids.

Model VI tends to overestimate the proportion of metals $(\mathrm{Cu}, \mathrm{Cr}$ and $\mathrm{REE})$ bound to humic substances (Fig. 8). It is important to note that the $<5 \mathrm{kDa}$ fraction is considered as free species, which is not true as fulvic acids are characterized by lower molecular weight. Thus, if all these elements $(\mathrm{Cu}, \mathrm{Cr}$ and $\mathrm{REE})$ are considered to be bound to organic ligands due to the good correlation they formed with DOC, model calculation results are in good agreement for these elements.

\subsection{Limitations of Model VI speciation calculations}

Although the $5 \mathrm{kDa}$ cut-off allow very small colloids to stay in solution, the lack of integration of adsorption processes onto inorganic species, as well as coprecipitation of inorganic species appear to be the major causes of disagreement between ultrafiltration data and speciation calculations for $\mathrm{V}$ and REE. It is then important to be aware that such model does not take into account any uptake of metals resulting from competitive reactions between Fe- and DOC-rich colloids. Moreover as stated by Unsworth et al. (2006) model predictions of free ions activities generally did not agree with measurement (e.g. for $\mathrm{Cd}, \mathrm{Cu}, \mathrm{Ni}$ and $\mathrm{Zn}$ ), highlighting the need for further work and difficulties in obtaining appropriate data.

The studied samples are organic-rich groundwaters with an organic pool that seems to be in excess regards to the metals available for complexation: in such samples the speciation appears to be constrained only by organic species. But, what does happen when the samples 
are organic-poor? Oxides, hydroxides, clay minerals, and organic matter present in the natural system become all potential sites for adsorption. Scavenging between oxyhydroxides and organic matter will occur and form ternary surface complex (surface/ligand/metal). However, such a competition is still difficult to interpret from ultrafiltration data. As evidenced by previously experimental data and calculations, it appears that the competitive reactions and the formation of ternary surface complexes on oxyhydroxides represent the major interferences of the organic ligands on metal adsorption (Buerge-Weirich et al., 2003). Cation ligand complexes can adsorb onto solid to form ternary surface complexes either, as cation linked to the mineral surface over the ligand or as ligand linked to the surface over the cation. As an example, recently published experimental REE data (Davranche et al., 2004; 2005) show the impact of ternary surface complexes (humates/oxyhydroxides/REE) on metal speciation. Thus, it appears absolutely necessary to take into account in such speciation models, processes such as adsorption onto $\mathrm{Mn}$ and $\mathrm{Fe}$ oxyhydroxides, considering that the lack of such reaction precludes any true speciation to be assessed, the competition between Fe and C-based colloidal carriers being required for constraining element geochemical cycles or element fate in polluted environments.

\section{Conclusions}

An ultracentrifugation method that allows the study of DOM-trace metal distribution at different pore size cut-offs was tested on two shallow, circumneutral $\mathrm{pH}$ waters: one dissolved DOC- and Fe-rich and a second DOC-rich and Fe-poor. Data were analyzed using an ascendant hierarchical classification. Three groups of elements were identified regards to their

affinity for DOM, which implies several consequences regards to their respective bioavailability or fate in the environment: (i) a "truly" dissolved behaviour group ( $\mathrm{Na}, \mathrm{K}, \mathrm{Rb}$, 
$\mathrm{Ca}, \mathrm{Mg}, \mathrm{Ba}, \mathrm{Sr}, \mathrm{Si}$ and $\mathrm{Ni}$ ), (ii) an inorganic colloidal pool (Fe, Al and $\mathrm{Th}$ ) and (iii) an organic colloidal pool (Cr, Mn, Co, Cu and U). However, REE and V have an ambivalent behaviour, being alternatively in the organic pool and in the inorganic pool depending on sample. Moreover, speciation calculation using Model VI were performed on both samples on some elements (Ca, Mg, Ni, Fe, Al, Th, Cr, Cu, Dy, Eu). Calculation shows relatively comparable elemental distribution with regards to ultrafiltration. Although some limitations appear: a direct use of ultrafiltration results tends to overestimate the fraction of elements bound to humic material in the inorganic pool as well as, a direct use of speciation calculation results tends to overestimate the fraction of elements bound to humic material in the organic pool with regards to ultrafiltration data. Both techniques, ultrafiltration and speciation calculation, give complementary information, especially for more complex samples where inorganic and organic colloids compete. The formation of water-soluble complexes between humic materials and metal ions (radioactive, toxic or none) can increase the concentrations of these species in natural water to higher levels than expected from their thermodynamic solubilities. Since the retention, transport and fate of trace metals mediated by organic matter has still to be better constrained to understand the functional role played by DOM at the soil-water interface regards to trace metal dynamics, further studies dedicated to space- and time-linked variations of the joined colloidal pool and trace element partitioning has to be now undertaken in waters from different DOM-rich environments.

\section{Acknowledgments}

We thank the technical staff and undergraduates at Geosciences Rennes Laboratory for their assistance during the experimental and analytical work. Dr. R.E. Martinez is deeply acknowledged for English corrections. This research was supported by the CPER programs 
"Développement de la Recherche sur la Maîtrise de la Qualité de l'Eau en Bretagne" jointly funded by the French Government and the Council of Rennes Métropole. Two anonymous reviewers are acknowledge for their useful advice and Dr. S. Smith is acknowledge for editorial handling. 


\section{References}

Ahrland, S., Chatt, S.J., Davies, N.R., 1958. The relative affinities of ligand atoms for acceptor molecules and ions. Q. Rev. Chem. Soc. London 12, 265-276.

Aiken, G.R., McKnight, D.M., Wershaw, R.L., MacCarthy, P., 1985. Humic substances in soil, sediment and water: Geochemistry, isolation and characterization. John Wiley and Sons, New York.

Bau, M., 1999. Scavenging of dissolved yttrium and rare earths by precipitating iron hydroxides: experimental evidence for Ce oxidation and lanthanide tetrad effect. Geochim. Cosmochim. Acta 63, 67-77.

Benedetti, M.F., Van Riemsdijk, W.H., Koopal, L.K, Kinniburg, D.G., Milne, C.J., 1996. Metal ion binding to natural organic matter: from the model to the field. Geochim. Cosmochim. Acta 60, 2503-2513.

Bennett, P., Siegel, D.I., 1987. Increased solubility of quartz in water due to complexing by organic compounds. Nature 326, 684-686.

Buerge-Weirich, D., Behra, P., Sigg, L., 2003. Adsorption of copper, nickel, and cadmium on goethite in the presence of organic ligands. Aquat. Chem. 9, 65-85.

Braun, J.J., Ndam Ngoupayou, J.R., Viers, J., Dupré, B., Bedimo Bedimo, J.P., Boeglin, J.L., Robain, H., Nyeck, B., Freydier, R., Sigha Nkamdjou, L., Rouiller, J., Müller, J.P., 2005. Present weathering rates in a humid tropical watershed: Nsimi, South Cameroon. Geochim. Cosmochim. Acta 69, 357-387.

Buffle, J., 1988. Complexation reactions in aquatic systems: an analytical approach. Ellis Norwood, Chichester.

Cabaniss, S.E., Schumann, M., 1988. Copper binding by dissolved organic matter. I ; Suwannee river fulvic acid equilibria. Geochim. Cosmochim. Acta 52, 185-193. 
Christensen, J.B., Jensen, D.L., Christensen, T.H., 1996. Effect of dissolved organic carbon on the mobility of cadmium, nickel, and zinc in leachate polluted groundwater. Wat. Res. 30, 3067-3049.

Curmi, P., Durand, P., Gascuel-Odoux, C., Hallaire, V., Mérot, P., Robin, P., Trolard, F., Walter, C., Bourrié, G., 1995. Le programme CORMORAN-INRA: de l'importance du milieu physique dans la régulation biogéochimique de la teneur en nitrate des eaux superficielles. J. Europ. Hydrol. 26, 37-56.

Dabard, M.P., Loi, A., Peucat, J.J., 1996. Zircon typology combined with Sm-Nd whole rock isotope analysis to study Brioverian sediments from the Armorican Massif. Sedim. Geol. $101,243-260$.

Dahlquist, R., Benedetti, M.F., Andersson, K., Turner, D., Larsson, T. Stolpe, B. Ingri, J., 2004. Association of calcium with colloidal particles and speciation of calcium in the Kalix and amazon rivers. Geochim. Cosmochim. Acta 68, 4059-4075.

Davranche, M., Pourret, O., Gruau, G., Dia, A., 2004. Impact of humate complexation on the adsorption of REE onto Fe oxyhydroxide. J. Colloid Int. Sci. 277, 271-279.

Davranche, M., Pourret, O., Gruau, G., Dia, A., Le Coz-Bouhnik, M., 2005. Adsorption of REE(III)-humate complexes onto $\mathrm{MnO}_{2}$ : Experimental evidence for cerium anomaly and lanthanide tetrad effect suppression. Geochim. Cosmochim. Acta 69, 4825-4835.

Dia, A., Gruau, G., Olivié-Lauquet, G., Riou, C., Molénat, J., Curmi, P., 2000. The distribution of rare earth elements in groundwaters: assessing the role of source-rock composition, redox changes and colloidal particles. Geochim. Cosmochim. Acta 64, 41314151.

Dillon, W.R., Goldstein, M., 1984. Multivariate analysis: Methods and applications. Wiley, New-York. 
Dupré, B., Viers, J., Dandurand, J.-L., Polvé, M., Bénézeth, P., Vervier, P., Braun, J.J., 1999. Major and trace elements associated with colloids in organic-rich river waters : ultrafiltration of natural and spiked solutions. Chem. Geol. 160, 63-80.

Durand, P., Juan Torres, J.L., 1996. Solute transfer in agricultural catchments: the interest and limits of the models. J. Hydrol. 181, 1-22.

Eyrolle, F., Benedetti, M.F., Benaim, J.Y., Février, D., 1996. The distributions of colloidal and dissolved organic carbon, major elements, and trace elements in small tropical catchments. Geochim. Cosmochim. Acta 60, 3643-3656.

Geckeis, H., Ngo Mahn, Th., Bouby, M., Kim, J.I., 2003. Aquatic colloids relevant to radionuclide migration/characterization by size fractionation and ICP-mass spectrometric detection. Colloids and Surface A: Physicochem. Eng. Aspects 00, 1-8.

Gruau, G., Dia, A., Olivié-Lauquet, G., Davranche, M., Pinay, G., 2004. Controls on the distribution of rare earth elements in shallow groundwaters. Wat. Res. 38, 3576-3586.

Iler, R.K., 1979. The geochemistry of colloid systems for earth scientists. By S. Yariv \& H. Cross. Springer-Verlag, Berlin, Heidelberg and New York. 1979 Book review. J. Colloid. Interf. Sci. 72, 177-178.

Ingri, J., Winderlund, A., Land, M., Gustafsson, O., Andersson, P., Ohlander, B., 2000. Temporal variations in the fractionation of the rare earth elements in a boreal river: the role of colloidal particles. Chem. Geol. 166, 23-45.

Jaffrézic, A., 1997. Géochimie des éléments métalliques, des nitrates et du carbone organique dissous dans les eaux et les sols hydromorphes. Agriculture intensive et qualité des eaux dans les zones humides en Bretagne. Ph.D. dissertation, University Rennes I (France).

Johannesson, K.H., Tang, J., Daniels, J.M., Bounds, W.J., Burdige, D.J., 2004. Rare earth element concentrations and speciation in organic-rich blackwaters of the Great Dismal Swamp, Virginia, USA. Chem. Geol. 209, 271-294. 
Lyven, B., Hassellöv, M., Turner, D.R., Haraldsson, C., Anderssson, K., 2003. Competition between iron- and carbon-based colloidal carriers for trace metals in a freshwater assessed using flow field-flow fractionation coupled to ICP-MS. Geochim. Cosmochim. Acta 67, $3791-3802$.

Macalady, D.L., 1998. Perspectives in environmental chemistry. Oxford University Press.

McCarty, J.F., Sanford, W.E., Stafford, P.L., 1998. Lanthanide field tracers demonstrate enhanced transport of transuranic radionuclides by natural organic matter. Environ. Sci. Technol. 32, 3901-3906.

Molénat, J., Durand, P., Gascuel-Odoux, C., Davy, P., Gruau, G., 2002. Mechanisms of nitrate transfer from soil to stream in an agricultural watershed of French Brittany. Water, Air and Soil Pollution 133, 161-183.

Nieboer, E., Richardson, D.H.S., 1980. The replacement of the nondescriptive term heavy metals by a biologically and chemically significant classification of metal ions. Environ. Pollut. Ser.B 1, 3-26.

Pauwels, H., Kloppmann, W., Foucher, J. C., Martelat, A., Fritsche, V., 1998. Field tracer test for denitrification in a pyrite-bearing schist aquifer. Applied Geochem. 13, 767-778.

Pellerin, J., Van Vliet-Lanoë, B., 1994. Cadre géomorphologique du bassin du Coët-Dan et du Haut Evel (Morbihan) : Rapport sur les travaux de cartographie et de stratigraphie. Unpublished Ph-D Thesis. Brest University, France.

Pokrovski, G.S., Schott, J., 1998. Experimental study of the complexation of silicon and germanium with aqueous organic species: implications for germanium and silicon transport and Ge/Si ratio in natural waters. Geochim. Cosmochim. Acta 62, 3413-3428.

Pokrovsky, O.S, Schott, J., 2002. Iron colloids/organic matter associated transport of major and trace elements in small boreal rivers and their estuaries (NW Russia). Chem. Geol. $190,141-179$. 
Pourret, O., Davranche, M., Gruau, G., Dia, A., 2006. Organic complexation of rare earth elements in natural waters: Evaluating model calculations from ultrafiltration data. Geochim. Cosmochim. Acta, Revised version submitted.

Shapiro, J., 1964. Effect of yellow organic acids on iron and other metals in water. Am. Water Works Assoc. J. 55, 1062-1082.

Schmitt, D., Saravia, F., Frimmel, F.H., Schuessler, W., 2003. NOM-facilitated transport of metal ions in aquifers: importance of complex-dissociation kinetics and colloid formation. Wat. Res. 37, 3541-3550.

Sigg, L., Xue, H., Kistler, D., Schönenberger, R., 2000. Size fractionation (dissolved, colloidal and particulate) of trace metals in Thur river, Switzerland. Aquat. Geochem. 6, 413-434.

Sholkovitz, E. R., 1995. The aquatic chemistry of rare earth elements in river and estuaries. Aquat. Geochem. 1, 1-34.

Stumm,W., Morgan, J.J., 1996. Aquatic chemistry. John Wiley and Sons. New York.

Tanizaki, Y., Shimokawa, T., Nakamura, M., 1992. Physicochemical speciation of trace elements in river waters by size fractionation. Environ. Sci. Tech. 26, 1433-1444.

Tipping, E., Hurley, M.A., 1992. A unifying model of cation binding by humic substances. Geochim. Cosmochim. Acta 56, 3627-3641.

Tipping, E., Rey-Castro, C., Bryan, S. E., Hamilton-Taylor, J., 2002. Al(III) and Fe(III) binding by humic substances in freshwaters, and implication for trace metal speciation. Geochim. Cosmochim. Acta 66, 3211-3224.

Tipping, E., 1998. Humic Ion-Binding Model VI: an improved description of the interactions of protons and metal ions with humic substances. Aquat. Geochem. 4, 3-48.

Tosiani, T., Loubet, M., Viers, J., Valladon, M., Tapia, J., Marrero, S., Yanes, C., Ramirez, A., Dupré, B., 2004. Major and trace elements in river-borne materials from the Cuyuni 
basin (southern Venezuela): evidence for organo-colloidal control on the dissolved load and element redistribution between the suspended and dissolved load. Chem. Geol. 211, 305-334.

Unsworth E. R., Warnken K. W., Zhang H., Davison W., Black F., Buffle J., Cao J., Cleven R., Galceran J., Gunkel P., Kalis E., Kistler D., Van Leeuwen H. P., Martin M., Noël S., Nur Y., Odzak N., Puy J., Van Riemsdijk W., Sigg L., Temminghoff E., Tercier-Webber M.-L., Toepperwien S., Town R. M., Weng L., and Xue H., 2006. Model predictions of metal specition in freshwaters compared to measurements by in situ techniques. Environ. Sci. Technol. 40, 1942-1949.

Viers, J., Dupré, B., Polvé, M., Schott, J., Dandurand, J.-L., Braun, J.J., 1997. Chemical weathering in the drainage basin of a tropical watershed (Nsimi-Zoetele site, Cameroon): comparison between organic-poor and organic-rich waters. Chem. Geol. 140, 181-206.

Wells, M.L., Goldberg, E.D., 1991. Occurrence of small colloids in sea water. Nature 353, 342-346.

Xue, H., Sigg, L., 1993. Free cupric ion concentration and $\mathrm{Cu}(\mathrm{II})$ speciation in eutrophic lake. Limnol. Oceanogr. 38, 1200-1213.

Xue, H., Kistler, D., Sigg, L., 1995. Competition of copper and zinc for strong ligands in a eutrophic lake. Limnol. Oceanogr. 40, 1142-1152. 


\section{Figure captions}

Fig. 1. Sketch showing (a) topography, channel network geometry and geographical location of the Kervidy-Coët Dan subcatchment, and (b) sampling point locations (Wt: wetland samples; Rv: river samples). Discontinuous patterned areas located close to the channel network indicate the location of wetland zones.

Fig. 2. Dendograms of samples a) PF1 and b) PF3 showing the hierarchical classification of the elements in three clusters.

Fig. 3. DOC concentrations versus Molecular Weight Cut-Offs. Values for molecular weight are approximated, since the spatial extension of macromolecules such as humic substances is depending on molecular structure and surrounding conditions. FA: Fulvic Acid; HA: Humic Acid.

Fig. 4. Variations of (a) $\mathrm{Rb}$ and (b) $\mathrm{Mg}$ concentrations versus DOC concentrations in the different filtrates. Errors bars correspond to standard deviation for two replicates, some errors bars are within the symbol size.

Fig. 5. Variations of (a) $\mathrm{Cu}$ and (b) $\mathrm{U}$ concentrations versus DOC concentrations in the different filtrates. Errors bars correspond to standard deviation for two replicates, some errors bars are within the symbol size. 
Fig. 6. Variations of (a) Al, (b) Fe, (c) Th concentrations versus DOC concentrations and (d) Th concentrations versus $\mathrm{Al}$ concentrations in the different filtrates. Errors bars correspond to standard deviation for two replicates, some errors bars are within the symbol size.

Fig. 7. Variations of REE concentrations versus (a) DOC and (b) Fe concentrations, and V concentrations versus (c) DOC and (d) Al concentrations in the different filtrates. Errors bars correspond to standard deviation for two replicates, some errors bars are within the symbol size.

Fig. 8. Proportion of elements complexed with humic substances calculated (with Model VI) versus proportion of elements complexed with humic substances observed (by ultrafiltration).

\section{Table captions}

Table 1. Ultrafiltration results, all concentrations are expressed in ppb, except $\mathrm{Cl}^{-}, \mathrm{NO}_{3}{ }^{-}, \mathrm{SO}_{4}{ }^{2-}$

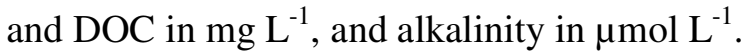

Table 2. Speciation calculations results: proportion of elements complexed with humic substances. 


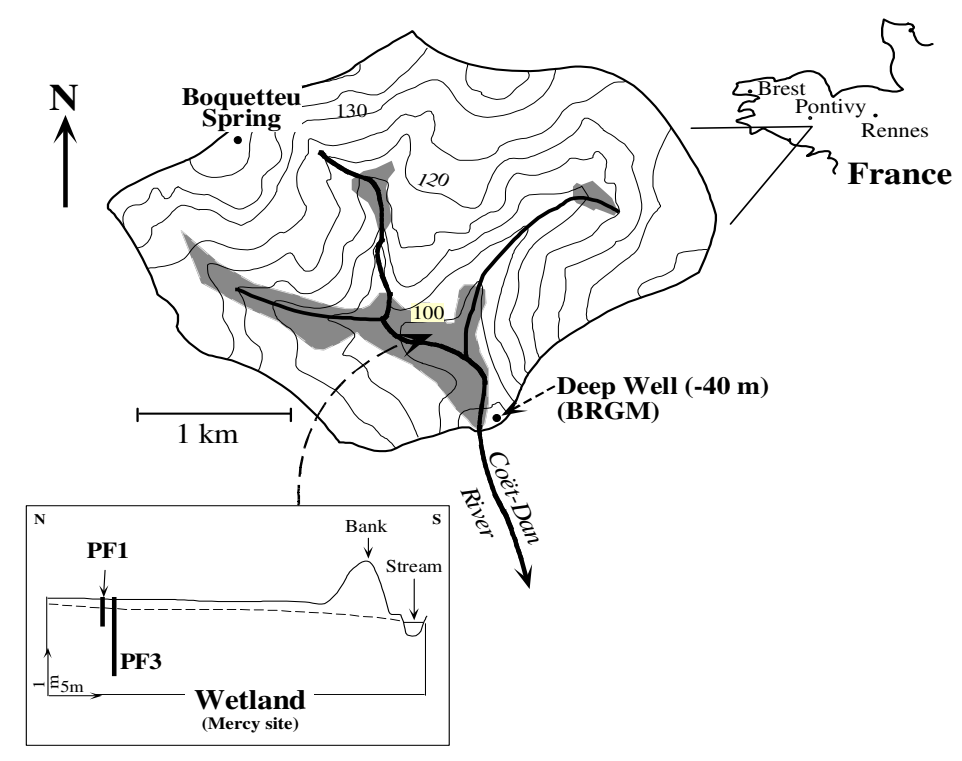

Fig. 1. 
(a) PF1

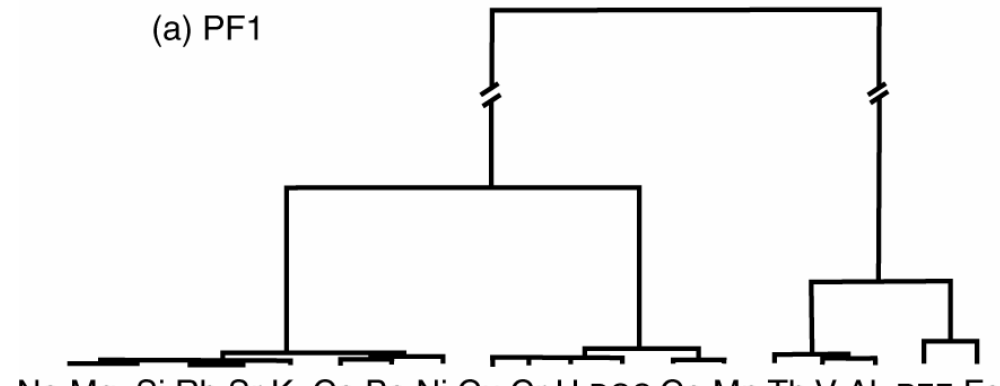

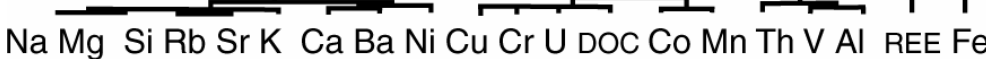

(b) PF3

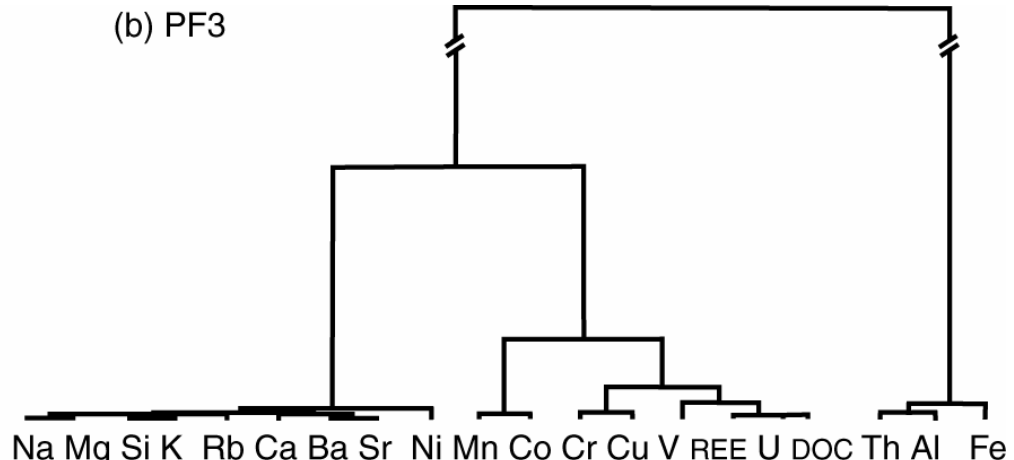

Fig. 2. 


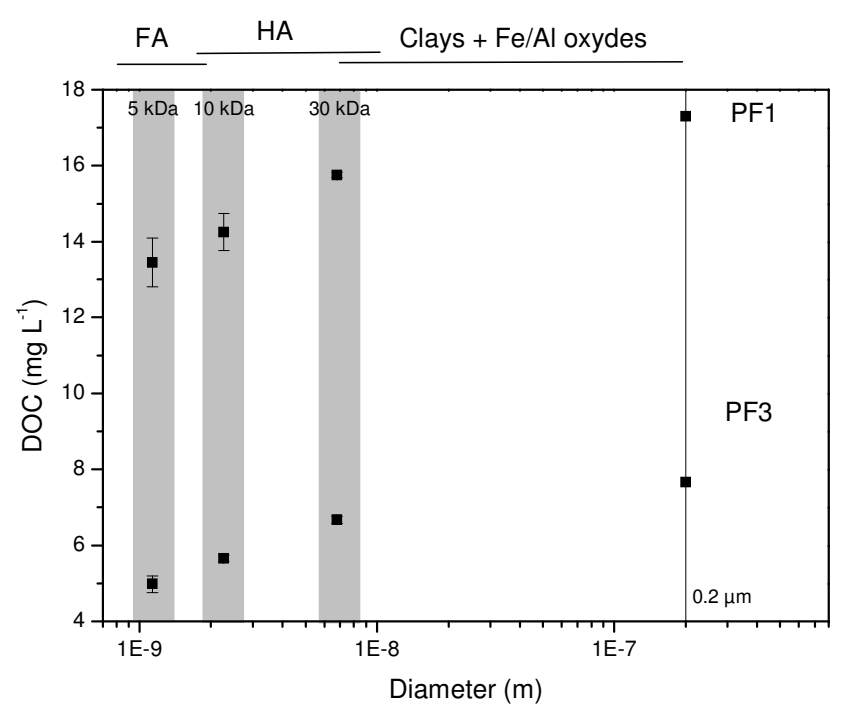

Fig. 3. 

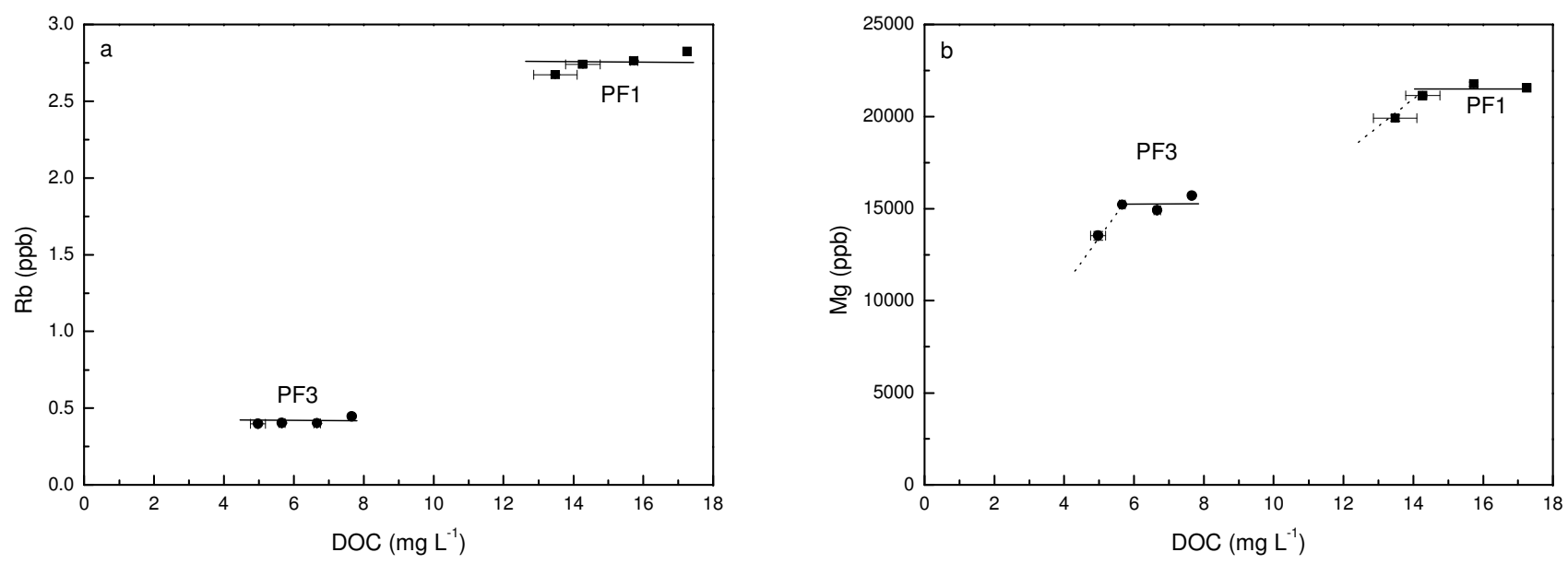

Fig. 4. 

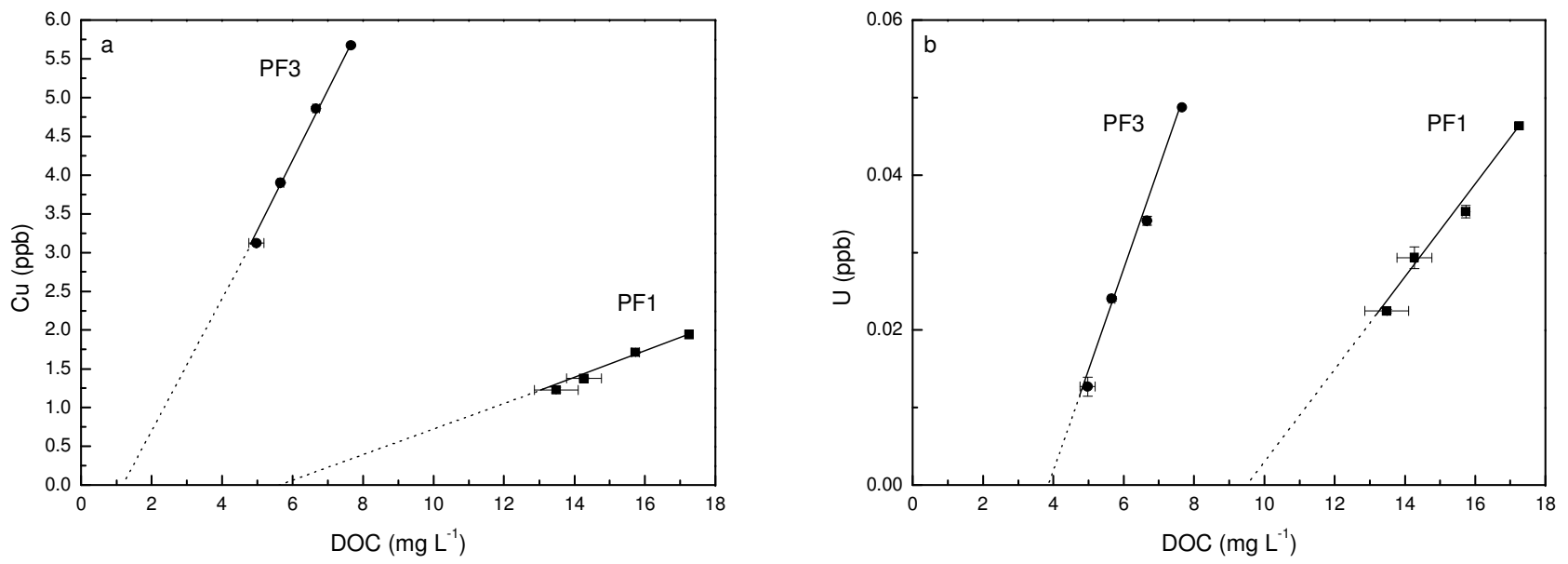

Fig. 5.

36 

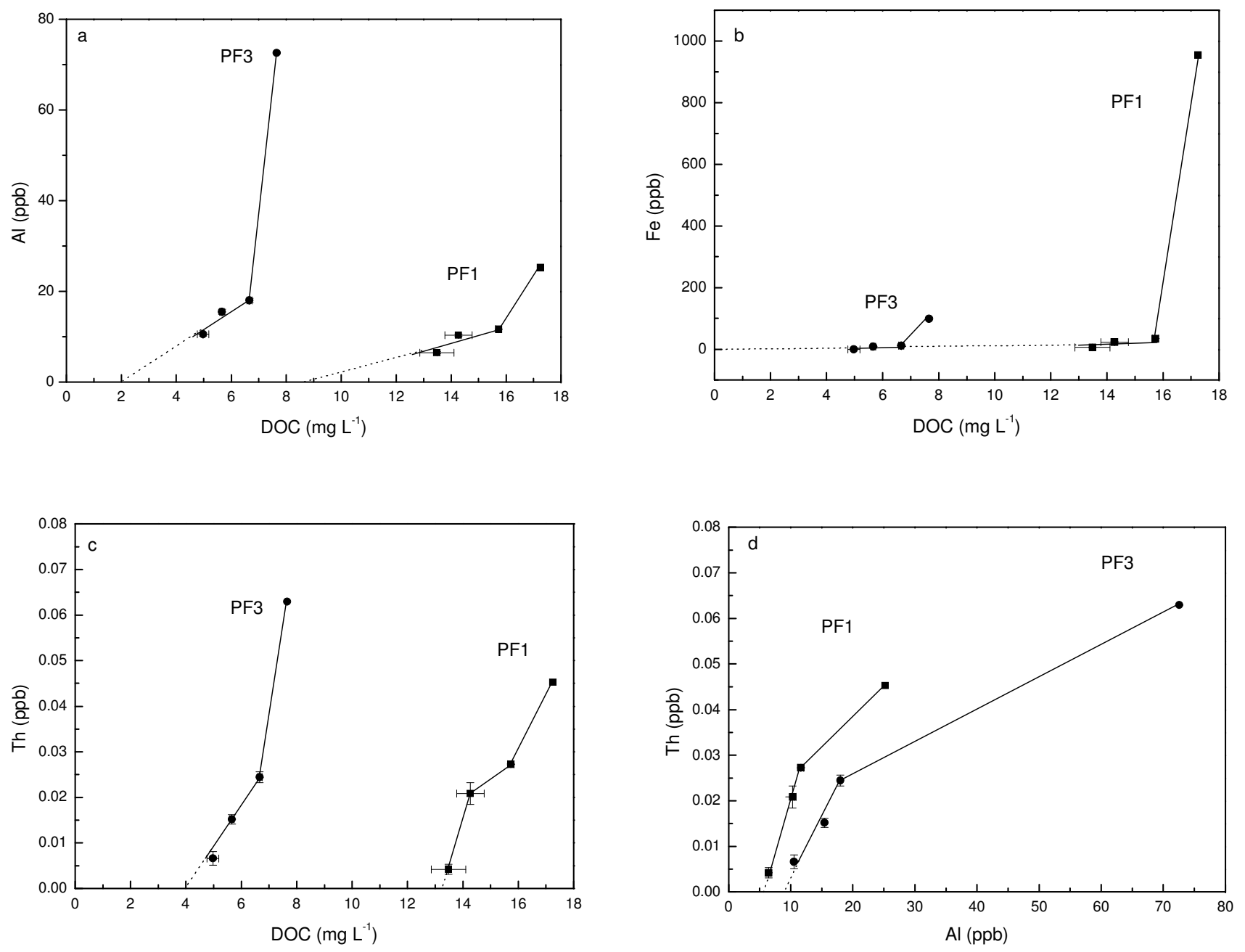

Fig. 6. 

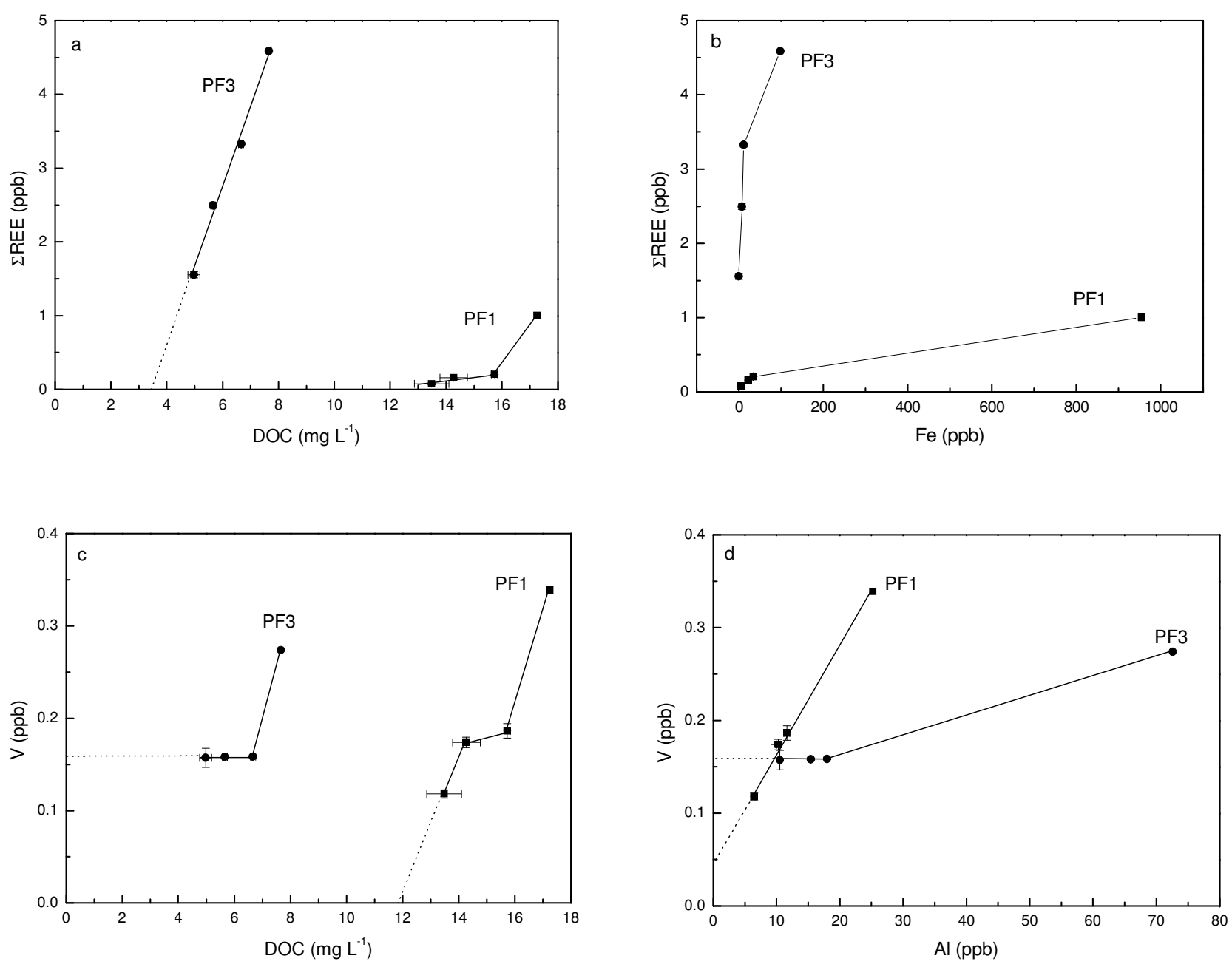

Fig. 7. 


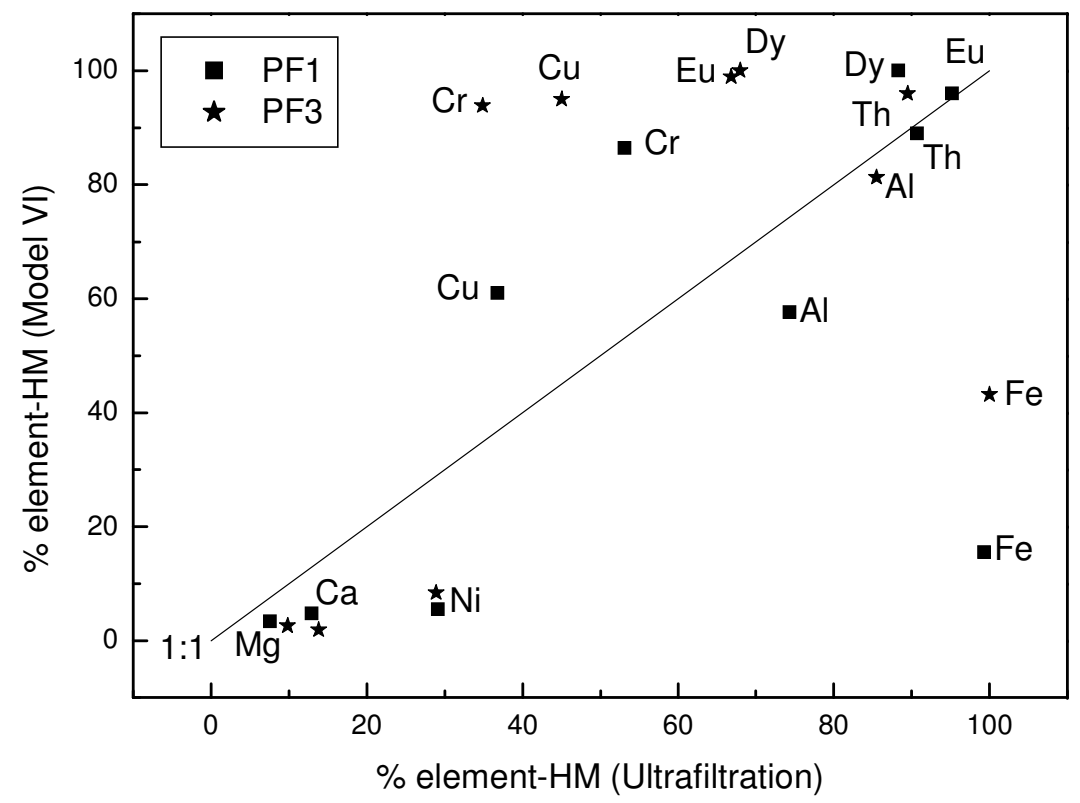

Fig. 8. 


\begin{tabular}{|c|c|c|c|c|c|c|c|c|c|c|c|c|c|c|}
\hline & $\begin{array}{c}\text { PF1 } \\
0.2 \mu \mathrm{m}\end{array}$ & $30 \mathrm{kDa}$ & $30 \mathrm{kDa}$ & $10 \mathrm{kDa}$ & $10 \mathrm{kDa}$ & $5 \mathrm{kDa}$ & $5 \mathrm{kDa}$ & $\begin{array}{c}\text { PF3 } \\
0.2 \mu \mathrm{m}\end{array}$ & $30 \mathrm{kDa}$ & $30 \mathrm{kDa}$ & $10 \mathrm{kDa}$ & $10 \mathrm{kDa}$ & $5 \mathrm{kDa}$ & $5 \mathrm{kDa}$ \\
\hline $\mathrm{T}\left({ }^{\circ} \mathrm{C}\right)$ & 10.6 & & & & & & & 10.7 & & & & & & \\
\hline $\mathrm{pH}$ & 7.08 & & & & & & & 6.93 & & & & & & \\
\hline $\mathrm{Cl}$ & 47 & & & & & & & 37 & & & & & & \\
\hline SO4 & 10 & & & & & & & 9 & & & & & & \\
\hline NO3 & 2 & & & & & & & 46 & & & & & & \\
\hline Alkalinity & 1867 & & & & & & & 385 & & & & & & \\
\hline DOC & 17.3 & 15.7 & 15.8 & 13.9 & 14.6 & 13.9 & 13.0 & 7.66 & 6.73 & 6.60 & 5.60 & 5.72 & 5.13 & 4.82 \\
\hline $\mathrm{Na}$ & 17130 & 17480 & 17300 & 16850 & 16580 & 15797 & 16187 & 16150 & 14950 & 15310 & 15400 & 15550 & 13015 & 13466 \\
\hline $\mathrm{Mg}$ & 21550 & 21690 & 21850 & 21170 & 21110 & 19801 & 20039 & 15710 & 14980 & 14850 & 15220 & 15220 & 13363 & 13705 \\
\hline $\mathrm{Al}$ & 25 & 12 & 12 & 11 & 10 & 6 & 7 & 72.6 & 18.4 & 17.7 & 15.8 & 15.0 & 10.8 & 10.3 \\
\hline $\mathrm{Si}$ & 4027 & 4013 & 4042 & 3903 & 3882 & 3751 & 3781 & 4234 & 3922 & 3946 & 4007 & 4048 & 3656 & 3679 \\
\hline $\mathrm{K}$ & 564 & 546 & 555 & 546 & 537 & 501 & 510 & 468 & 426 & 434 & 441 & 435 & 400 & 403 \\
\hline $\mathrm{Ca}$ & 10310 & 10050 & 10190 & 9717 & 9218 & 8915 & 9033 & 7437 & 7088 & 7539 & 7371 & 7151 & 6686 & 6719 \\
\hline $\mathrm{V}$ & 0.34 & 0.18 & 0.19 & 0.18 & 0.17 & 0.11 & 0.12 & 0.27 & 0.16 & 0.16 & 0.16 & 0.16 & 0.16 & 0.15 \\
\hline $\mathrm{Cr}$ & 1.36 & 1.16 & 1.15 & 1.08 & 1.00 & 0.61 & 0.67 & 0.87 & 0.69 & 0.68 & 0.67 & 0.69 & 0.59 & 0.54 \\
\hline Mn & 31.16 & 25.40 & 25.27 & 24.87 & 24.63 & 9.55 & 9.66 & 9.77 & 9.40 & 9.41 & 9.34 & 9.49 & 2.65 & 2.67 \\
\hline $\mathrm{Fe}$ & 955 & 35 & 34 & 21 & 25 & 6 & 7 & 98.5 & 12.1 & 11.6 & 8.0 & n.a. & 0.0 & 0.0 \\
\hline Co & 3.75 & 3.10 & 3.10 & 2.85 & 2.78 & 1.16 & 1.23 & 1.13 & 1.07 & 1.07 & 1.04 & 1.10 & 0.20 & 0.20 \\
\hline $\mathrm{Ni}$ & 5.52 & 5.15 & 5.44 & 4.90 & 4.97 & 3.80 & 4.03 & 6.45 & 5.94 & 5.91 & 5.75 & n.a. & 4.59 & 4.57 \\
\hline $\mathrm{Cu}$ & 1.94 & 1.70 & 1.72 & 1.39 & 1.37 & 1.20 & 1.25 & 5.68 & 4.84 & 4.88 & 3.91 & 3.90 & 3.12 & 3.12 \\
\hline $\mathrm{Zn}$ & 5.69 & cntd & cntd & cntd & cntd & cntd & cntd & 11.74 & cntd & cntd & cntd & cntd & cntd & cntd \\
\hline $\mathrm{Rb}$ & 2.83 & 2.77 & 2.76 & 2.75 & 2.73 & 2.67 & 2.67 & 0.45 & 0.40 & 0.40 & 0.41 & 0.40 & 0.40 & 0.40 \\
\hline $\mathrm{Sr}$ & 57.18 & 55.87 & 55.75 & 55.07 & 54.60 & 53.43 & 53.56 & 51.56 & 50.82 & 50.61 & 50.39 & 50.34 & 49.98 & 50.27 \\
\hline $\mathrm{Ba}$ & 7.28 & 6.65 & 6.72 & 6.58 & 6.51 & 6.32 & 6.26 & 10.71 & 10.48 & 10.39 & 10.35 & 10.26 & 10.18 & 10.18 \\
\hline
\end{tabular}

Table 1. (to be continued) 


\begin{tabular}{|c|c|c|c|c|c|c|c|c|c|c|c|c|c|c|}
\hline \multicolumn{3}{|c|}{ PF1 } & \multicolumn{12}{|c|}{ PF3 } \\
\hline & $0.2 \mu \mathrm{m}$ & $30 \mathrm{kDa}$ & $30 \mathrm{kDa}$ & $10 \mathrm{kDa}$ & $10 \mathrm{kDa}$ & $5 \mathrm{kDa}$ & $5 \mathrm{kDa}$ & $0.2 \mu \mathrm{m}$ & $30 \mathrm{kDa}$ & $30 \mathrm{kDa}$ & $10 \mathrm{kDa}$ & $10 \mathrm{kDa}$ & $5 \mathrm{kDa}$ & $5 \mathrm{kDa}$ \\
\hline $\mathrm{La}$ & 0.176 & 0.029 & 0.029 & 0.021 & 0.021 & 0.010 & 0.012 & 0.804 & 0.580 & 0.571 & 0.436 & 0.430 & 0.284 & 0.274 \\
\hline $\mathrm{Ce}$ & 0.365 & 0.059 & 0.060 & 0.045 & 0.044 & 0.019 & 0.029 & 1.889 & 1.352 & 1.347 & 1.027 & 0.996 & 0.600 & 0.578 \\
\hline $\operatorname{Pr}$ & 0.055 & 0.011 & 0.011 & 0.007 & 0.008 & 0.004 & 0.004 & 0.255 & 0.184 & 0.185 & 0.140 & 0.138 & 0.095 & 0.091 \\
\hline $\mathrm{Nd}$ & 0.239 & 0.053 & 0.050 & 0.041 & 0.042 & 0.016 & 0.019 & 1.105 & 0.833 & 0.819 & 0.630 & 0.618 & 0.417 & 0.404 \\
\hline $\mathrm{Sm}$ & 0.050 & 0.012 & 0.014 & 0.010 & 0.010 & 0.005 & 0.004 & 0.194 & 0.144 & 0.140 & 0.104 & 0.100 & 0.070 & 0.067 \\
\hline $\mathrm{Eu}$ & 0.010 & 0.003 & 0.003 & 0.003 & 0.002 & 0.000 & 0.001 & 0.037 & 0.027 & 0.026 & 0.019 & 0.019 & 0.012 & 0.012 \\
\hline $\mathrm{Gd}$ & 0.040 & 0.012 & 0.012 & 0.010 & 0.009 & 0.003 & 0.004 & 0.135 & 0.096 & 0.095 & 0.075 & 0.071 & 0.046 & 0.044 \\
\hline $\mathrm{Tb}$ & 0.005 & 0.001 & 0.002 & 0.001 & 0.001 & 0.000 & 0.001 & 0.013 & 0.010 & 0.009 & 0.007 & 0.007 & 0.004 & 0.004 \\
\hline Dy & 0.026 & 0.009 & 0.008 & 0.007 & 0.007 & 0.003 & 0.003 & 0.067 & 0.049 & 0.047 & 0.035 & 0.037 & 0.022 & 0.021 \\
\hline Ho & 0.005 & 0.002 & 0.002 & 0.002 & 0.002 & 0.001 & 0.001 & 0.013 & 0.009 & 0.010 & 0.007 & 0.007 & 0.004 & 0.004 \\
\hline $\mathrm{Er}$ & 0.015 & 0.006 & 0.007 & 0.006 & 0.005 & 0.002 & 0.002 & 0.035 & 0.027 & 0.026 & 0.019 & 0.020 & 0.012 & 0.013 \\
\hline $\mathrm{Tm}$ & 0.002 & 0.001 & 0.001 & 0.001 & 0.001 & 0.000 & 0.000 & 0.005 & 0.004 & 0.004 & 0.003 & 0.003 & 0.002 & 0.002 \\
\hline $\mathrm{Yb}$ & 0.015 & 0.006 & 0.007 & 0.006 & 0.005 & 0.002 & 0.003 & 0.030 & 0.025 & 0.023 & 0.018 & 0.018 & 0.012 & 0.012 \\
\hline $\mathrm{Lu}$ & 0.003 & 0.001 & 0.001 & 0.001 & 0.001 & 0.000 & 0.001 & 0.005 & 0.004 & 0.004 & 0.003 & 0.003 & 0.002 & 0.002 \\
\hline$\Sigma$ REE & 1.005 & 0.205 & 0.206 & 0.161 & 0.158 & 0.067 & 0.083 & 4.587 & 3.344 & 3.307 & 2.524 & 2.468 & 1.584 & 1.527 \\
\hline $\mathrm{Pb}$ & 0.784 & cntd & cntd & cntd & cntd & cntd & cntd & 0.128 & cntd & cntd & cntd & cntd & cntd & cntd \\
\hline $\mathrm{Th}$ & 0.045 & 0.027 & 0.027 & 0.023 & 0.019 & 0.003 & 0.005 & 0.063 & 0.025 & 0.024 & 0.016 & 0.014 & 0.008 & 0.006 \\
\hline $\mathrm{U}$ & 0.046 & 0.035 & 0.036 & 0.030 & 0.028 & 0.022 & 0.023 & 0.049 & 0.035 & 0.034 & 0.024 & 0.024 & 0.014 & 0.012 \\
\hline
\end{tabular}

Table 1.

\begin{tabular}{lcccccccccc}
\hline & $\mathrm{Mg}$ & $\mathrm{Al}$ & $\mathrm{Ca}$ & $\mathrm{Cr}$ & $\mathrm{Fe}$ & $\mathrm{Ni}$ & $\mathrm{Cu}$ & $\mathrm{Eu}$ & $\mathrm{Dy}$ & $\mathrm{Th}$ \\
\cline { 2 - 11 } PF1 & 3 & 58 & 5 & 86 & 16 & 6 & 61 & 96 & 100 & 89 \\
PF3 & 2 & 81 & 3 & 94 & 43 & 8 & 95 & 99 & 100 & 96 \\
\hline
\end{tabular}

Table 2. 